\title{
Optimization of supercritical carbon dioxide extraction of fat and cholesterol from beef floss by response surface methodology
}

\author{
${ }^{1,2}$ Noor Eliza, M.R., ${ }^{1}$ Siti Roha, A.M., ${ }^{1}$ Norrizah, A.R. and ${ }^{1, *}$ Adi, M.S. \\ ${ }^{1}$ Department of Food Science and Technology, Faculty of Applied Sciences, Universiti Teknologi MARA, \\ 40450 Shah Alam, Selangor, Malaysia. \\ ${ }^{2}$ National Public Health Laboratory, Ministry of Health, Malaysia, Lot 1853 Kampung Melayu, 47000 \\ Sungai Buloh, Selangor, Malaysia
}

\author{
Article history: \\ Received: 21 May 2020 \\ Received in revised form: 28 \\ July 2020 \\ Accepted: 16 August 2020 \\ Available Online: 8 \\ November 2020
}

Keywords:

Beef floss,

Supercritical carbon dioxide extraction,

Fat,

Cholesterol,

Optimization,

Response surface

methodology

\begin{abstract}
Supercritical carbon dioxide $\left(\mathrm{Sc}-\mathrm{CO}_{2}\right)$ was applied to extract fat and cholesterol from beef floss (BF). A response surface methodology (RSM) based on central composite design (CCD) was employed to optimize the extraction conditions of temperature $\left(30-62^{\circ} \mathrm{C}\right)$, pressure $(7-35 \mathrm{MPa})$, and extraction time ( 0 - $40 \mathrm{mins})$. The optimum conditions were estimated to be at $51.0^{\circ} \mathrm{C}$ and $32.8 \mathrm{MPa}$ for a duration of 32.7 mins. Under such conditions, the percentage of fat and cholesterol reduction plus lightness of $\mathrm{Sc}-\mathrm{CO}_{2}$ treated BF (STBF) were $81.12 \%, 86.17 \%$, and 57.60 , respectively. There were no significant differences $(p>0.05)$ between experimental and predicted values, indicating the adequacy of the well-fitting models. Furthermore, the protein and ash content of STBF increased significantly $(\mathrm{p}<0.05)$ as a result of the extraction. This study indicated that RSM-CCD can be potentially employed in maximizing the extraction of fat and cholesterol from BF under mild $\mathrm{Sc}-\mathrm{CO}_{2}$ conditions.
\end{abstract}

DOI:

https://doi.org/10.26656/fr.2017.5(1).239

\section{Introduction}

Restricting saturated fat in the daily diet has become an important strategy since a reduction in cholesterol consumption is recommended as a means of preventing heart diseases (McKenzie, 2002; Chapkin, 2007; Micha et al., 2010; Petrović et al., 2010; Kumar et al., 2012; Perk et al., 2012; Salimon et al., 2014; Torres-Moreno et al., 2015; Marzocchi et al., 2018; Soliman, 2018). In fact, according to the World Health Organization (WHO) data published in 2018 reported that coronary heart disease deaths in Malaysia reached 34,766 or $24.69 \%$ of total deaths (WHO, 2018). Evidence of the possible health implications of saturated fat and/or cholesterol underscores the need to produce 'low fat and/or cholesterol' or 'no fat and/or cholesterol' food products. It is, therefore, imperative to propose strategies for fat and cholesterol reduction in cooked and processed meats, especially with the ones derived from red meat due to the presence of intramuscular fat (Troy et al., 2016). Beef floss (BF) or locally known as Serunding Daging, is a popular cooked and dry meat product in Malaysia for its unique savoury taste. However, it is not necessarily associated with 'health' or 'clean' image for its high level of saturated fat and cholesterol content as a result of its product formulation and method of preparation (McKenzie, 2002).

Supercritical carbon dioxide $\left(\mathrm{Sc}-\mathrm{CO}_{2}\right)$ is an extraction method that employs carbon dioxide $\left(\mathrm{CO}_{2}\right)$ as the primary solvent at its critical points of $31.1^{\circ} \mathrm{C}$ and 7.38 MPa (Budisa and Schulze-Makuch, 2014). Unlike many organic solvents, $\mathrm{Sc}-\mathrm{CO}_{2}$ is safe, environmentally friendly, and non-carcinogenic (Darani and Mozafari, 2010; $\mathrm{Hu}$ and Deng, 2016). Response surface methodology (RSM) has been identified to be a powerful tool for optimizing different parameters affecting lipid extraction process to be conducted effectively (Higuera-Ciapara et al., 2005; Hou et al., 2010; Ghasemi et al., 2011; Taher et al., 2011; Wang et al., 2012; Chitra et al., 2015; Dey Pau et al., 2016; Zermane et al., 2016). Despite numerous reports on Sc$\mathrm{CO}_{2}$ technology to reduce fat and cholesterol from various lipid-based food products (Wehling et al., 1992; Froning et al., 1994; Froning et al., 1998; Mohamed et al., 1998; Lin et al., 1999; Wang et al., 2008; Bradley, 2010; Hou et al., 2010; Taher et al., 2011; Dey Paul et al., 2016), only two studies reported on the optimization of Sc- $\mathrm{CO}_{2}$ on fat and cholesterol reduction using RSM (Hou et al., 2010; Taher et al., 2011). RSM has been 
successfully employed to model and optimizes $\mathrm{Sc}-\mathrm{CO}_{2}$ extraction of fat and cholesterol from goat placenta (Hou et al., 2010) and fat extraction from lamb meat (Taher et al., 2011). However, these studies estimated the fat and cholesterol content from the raw or uncooked samples and direct quantification of the lipid following extraction was not carried out from the treated samples itself.

To the best of our knowledge, lipid extraction from cooked meat using $\mathrm{Sc}-\mathrm{CO}_{2}$ was only reported in beef meat (Wehling et al., 1992), chicken meat (Froning et al., 1994), and pork floss (Lin et al., 1999). These studies, however, reported the effect of temperature, pressure, and time on fat and cholesterol extraction and the $\mathrm{Sc}-\mathrm{CO}_{2}$ conditions were not optimized. The present work aims to determine the optimal $\mathrm{Sc}-\mathrm{CO}_{2}$ extraction of fat and cholesterol with a maximal reduction in fat and cholesterol from BF by using RSM. Additionally, the chemical composition and colour characteristics of the $\mathrm{Sc}-\mathrm{CO}_{2}$ treated $\mathrm{BF}$ (STBF) were compared with untreated $\mathrm{BF}$.

\section{Materials and methods}

\subsection{Materials}

A total of $1 \mathrm{~kg}$ of $\mathrm{BF}$ was purchased from a supermarket and kept at room temperature until analysis. All samples were well homogenized with a blender before analysis. The determination of cholesterol content was conducted with the use of chemicals such as potassium hydroxide $(\mathrm{KOH})$ and anhydrous sodium sulfate $\left(\mathrm{Na}_{2} \mathrm{SO}_{4}\right)$ from Merck, (Darmstadt, Germany), while toluene $\left(\mathrm{C}_{7} \mathrm{H}_{8}\right)$ and ethanol $\left(\mathrm{CH}_{3} \mathrm{CH}_{2} \mathrm{OH}\right)$ from Fisher Scientific (Pittsburgh, Pennsylvania). This study used cholesterol reference standard as an external standard ( $>99 \%$, United States Pharmacopeia, United States) and 5 $\alpha$-cholestane as an internal standard ( $>97 \%$, Sigma-Aldrich, United States). All standard solutions were stored at $4{ }^{\circ} \mathrm{C}$ and protected from light. Liquefied $\mathrm{CO}_{2}(99.95 \%)$, Helium (He), Nitrogen $\left(\mathrm{N}_{2}\right)$, Hydrogen $\left(\mathrm{H}_{2}\right)$, and zero air with ultra-high purity $(99.99 \%)$ were supplied by Poly Gas Sdn. Bhd. (Selangor, Malaysia). Ethanol (95\%, Fisher Scientific) was used to flush the Sc $-\mathrm{CO}_{2}$ extraction system. Petroleum ether (Fisher Scientific) was used for the fat analysis. 0.1 M Hydrochloric acid $\mathrm{HCl}$ (Merck), concentrated sulphuric acid $\mathrm{H}_{2} \mathrm{SO}_{4}$ (Merck), sodium hydroxide $\mathrm{NaOH}$ (Merck), boric acid (Merck), and Kjeldahl catalysts (FOSS) were used for the protein analysis. All chemicals and reagents used were of analytical grade.

\subsection{Design of experiment for Response Surface Methodology (RSM)}

Response surface methodology (RSM), based on implicating central composite design (CCD), was utilized to optimize the $\mathrm{Sc}-\mathrm{CO}_{2}$ conditions for the maximum removal of fat and cholesterol from BF. Three independent variables, namely temperature, pressure, and extraction time were coded as $X_{1}, X_{2}$, and $X_{3}$, respectively using five different levels $(-\alpha,-1,0,1$, and a) (Table 1). The response variables examined included the percentage of fat reduction $\left(\mathrm{Y}_{1}\right)$, percentage of cholesterol reduction $\left(\mathrm{Y}_{2}\right)$, and lightness $\left(\mathrm{Y}_{3}\right)$. A $2^{3}$ fullfraction CCD was applied for response surface fitting. The total number of experiments was $20\left(2^{\mathrm{k}}+2 \mathrm{k}+6\right.$, where $\mathrm{k}$ represents the number of independent variables; in this study, $\mathrm{k}=3$ ), including six replications at the centre point. The 20 experimental runs, which resulted in obtained data response variables were shown in Table 2. All the experimental runs were replicated two times to provide reliable data. Later, the mean data was used for response surface application.

Table 1. Coded levels and uncoded independent variables used in the response surface methodology based on central composite design (RSM-CCD) design

\begin{tabular}{|c|c|c|c|c|c|c|}
\hline \multirow{2}{*}{$\begin{array}{l}\text { Independent } \\
\text { Variables }\end{array}$} & \multirow{2}{*}{ Symbols } & \multicolumn{5}{|c|}{ Coded Levels } \\
\hline & & -1.68 & -1 & 0 & 1 & 1.68 \\
\hline Temperature $\left({ }^{\circ} \mathrm{C}\right)$ & $\mathrm{X}_{1}$ & 30 & 38 & 46 & 54 & 62 \\
\hline Pressure (MPa) & $\mathrm{X}_{2}$ & 7 & 14 & 21 & 28 & 35 \\
\hline $\begin{array}{l}\text { Extraction time } \\
(\mathrm{min})\end{array}$ & $\mathrm{X}_{3}$ & 0 & 10 & 20 & 30 & 40 \\
\hline
\end{tabular}

A full second-order polynomial model of the design was applied to evaluate the response variables $\left(\mathrm{Y}_{1}, \mathrm{Y}_{2}\right.$, and $\mathrm{Y}_{3}$ ) of $\mathrm{BF}$ as a function of the independent variables $\left(\mathrm{X}_{1}, \mathrm{X}_{2}\right.$, and $\left.\mathrm{X}_{3}\right)$ as well as their interactions. The generalized second-order polynomial model used in the response surface analysis as follows:

$\mathrm{Y}=\mathrm{b} 0+\mathrm{b} 1 \mathrm{X}_{1}+\mathrm{b} 2 \mathrm{X}_{2}+\mathrm{b} 3 \mathrm{X}_{3}+\mathrm{b} 4 \mathrm{X}_{1} \mathrm{X}_{1}+\mathrm{b} 5 \mathrm{X}_{2} \mathrm{X}_{2}+$ b6 $X_{3} X_{3}+b 7 X_{1} X_{2}+b 8 X_{1} X_{3}+b 9 X_{2} X_{3}$

where Y represents the predicted response variables, b0 is the value for the fixed response variables at the central point of the experiment, b1, b2, and b3 are linear coefficients, b4, b5, and b6 are square (quadratic) coefficients, and b7, b8, and b9 are interaction coefficients. Whereas $X_{1}, X_{2}$, and $X_{3}$ are independent variables in coded values.

\section{$2.3 \mathrm{Sc}-\mathrm{CO}_{2}$ extraction of fat and cholesterol}

A supercritical fluid system (JK5326001, Taiwan Supercritical Technology, Taiwan) was used for the Sc$\mathrm{CO}_{2}$ extraction of fat and cholesterol from $\mathrm{BF}$ according to the method demonstrated by Lin et al. (1999) with 


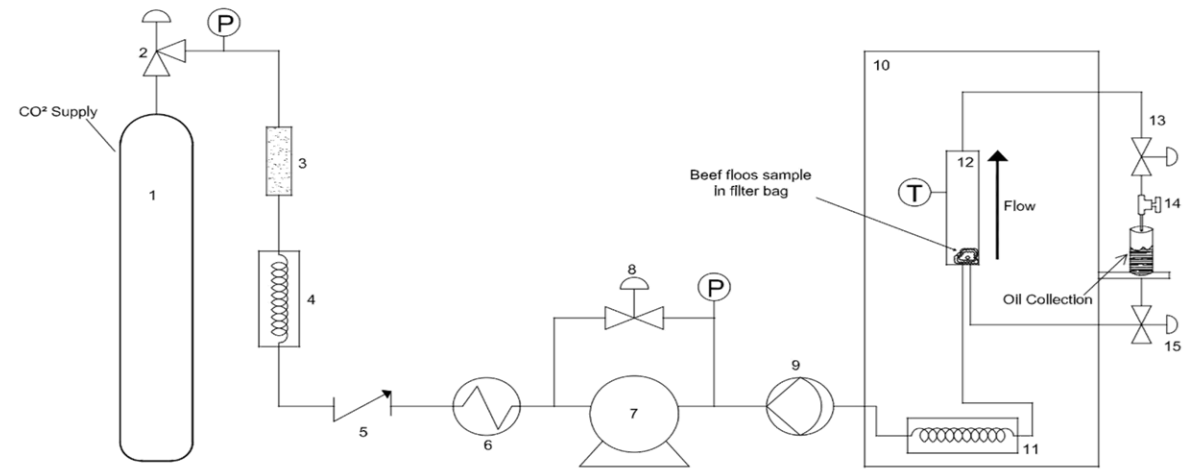

Figure 1. Schematic diagram of supercritical carbon dioxide $\left(\mathrm{Sc}-\mathrm{CO}_{2}\right)$ extraction apparatus set-up: (1) $\mathrm{CO}_{2}$ tank, (2) Tank valve, (3) Filter, (4) Transformer, (5) Check valve, (6) Cooler, (7) High-pressure gas compressor, (8) Back pressure regulator, (9) Pump, (10) Oven, (11) Preheater coil, (12) High-pressure treatment vessel, (13) Output valve, (14) Extraction valve, (15) Input valve, (P) Pressure gauge, (T) Thermocouple

minor modifications. The schematic diagram of $\mathrm{Sc}-\mathrm{CO}_{2}$ extraction apparatus used as shown in Figure 1. The extraction apparatus consisted of $\mathrm{CO}_{2}$ cylinder tank (No. 1), transformer (No. 4), cooler (No. 6), high-pressure gas compressor (No. 7), pump with a maximum capacity of $5000 \mathrm{MPa}$ (No. 9), oven (No. 10) and collection extraction system (No. 13-15). A $15 \mathrm{~g}$ of BF was weighed and packed in a tea bag filter and was loaded into the $60 \mathrm{~mL}$ extraction vessel (No. 12). The valve of the $\mathrm{CO}_{2}$ cylinder tank (No. 2) was opened and passed through the extraction vessel (No. 12), where the extraction of lipid was taken place. The flow rate of $\mathrm{CO}_{2}$ was kept constant at $10 \mathrm{~L} / \mathrm{min}$ throughout the extraction period. The $\mathrm{BF}$ was extracted at various temperatures, pressures, and extraction times based on experimental design, as shown in Table 2. After the extraction completed, then dried BF was kept for further analysis. A $50 \mathrm{~mL}$ of $95 \%$ ethanol was flushed at $45^{\circ} \mathrm{C}$ and 10.34 $\mathrm{MPa}$ to remove any residue from the extraction vessel.

\subsection{Determination of chemical composition of beef floss $(B F)$}

The chemical composition was carried out according to the method described by the Association of Official Analytical Chemists (AOAC, 2000). The fat content was determined by the Soxhlet extraction method (960.39 AOAC, 2000) with minor modification. The percentage of fat reduction $\left(\mathrm{Y}_{1}\right)$ was calculated by dividing the weight differences of the fat content in untreated BF and STBF (wt.\%) with the fat content of untreated BF (wt.\%), multiplied by 100 . Analysis of cholesterol was carried out using direct saponification to liberate cholesterol from BF according to Dinh et al. (2012). The free cholesterol was then quantified using gas chromatography with a flame ionization detector (GCFID) (Agilent $6890 \mathrm{GC}$ system). The GC-FID was set at $250^{\circ} \mathrm{C}$ inlet temperature with the split ratio $50: 1$. The GC oven was programmed at $260^{\circ} \mathrm{C}$ isothermally for $30 \mathrm{~min}$. The FID temperature was $350^{\circ} \mathrm{C}$ and fuelled by $450 \mathrm{~mL} /$ min and $40 \mathrm{~mL} / \mathrm{min}$ of air and hydrogen flow, respectively (Dinh et al., 2012). The makeup gas was $\mathrm{He}$, and the total of the constant column and makeup flows was $40 \mathrm{~mL} / \mathrm{min}$. The percentage of cholesterol reduction $\left(\mathrm{Y}_{2}\right)$ was calculated by dividing the weight differences of the cholesterol content in untreated BF and STBF $(\mathrm{mg} / 100 \mathrm{~g})$ by the cholesterol content of untreated BF (mg/100 g), multiplied by 100 . The content of protein was determined by the Kjeldahl method (928.08 AOAC, 2000), with a conversion factor of 6.25. The moisture content was analyzed by drying $2 \mathrm{~g}$ of samples at $135^{\circ} \mathrm{C}$ for $2 \mathrm{hrs}$ using the air-oven technique (950.46 AOAC, 2000). The ash content was measured by heating $3 \mathrm{~g}$ of sample in a furnace at $550^{\circ} \mathrm{C}$ for 17 hours $(920.153$ AOAC, 2000).

\subsection{Determination of colour of beef floss $(B F)$}

The colour characteristics of $\mathrm{BF}$ were measured using a Chroma Meter (CR-400, Konica Minolta, Japan). The Chroma meter was connected to Spectra Magic NX software and was calibrated using a standard white plate $(\mathrm{Y}=92.3, \mathrm{X}=0.3165, \mathrm{y}=0.3328)$. The colour of the BF samples was then measured in terms of lightness $\left(\mathrm{L}^{*}\right)$, redness $\left(\mathrm{a}^{*}\right)$, and yellowness $\left(\mathrm{b}^{*}\right)$ and integrated by the software. The net colour difference was evaluated with the following equation Chugh et al. (2014), using the L*, $a^{*}$ and $b^{*}$ coordinates, and comparing the STBF with untreated BF:

$$
\Delta E=\sqrt{\left(\Delta \mathrm{L}^{*}\right)^{2}+\left(\Delta \mathrm{a}^{*}\right)^{2}+\left(\Delta \mathrm{b}^{*}\right)^{2}}
$$

\subsection{Statistical analysis}

Minitab Software (ver. 17) was used for the analysis of variance (ANOVA), the multiple regression analysis, and the response surface regression. The one-way ANOVA was carried out to determine the effects of the independent variables $\left(\mathrm{X}_{1}, \mathrm{X}_{2}\right.$, and $\left.\mathrm{X}_{3}\right)$ to the response variables $\left(\mathrm{Y}_{1}, \mathrm{Y}_{2}\right.$, and $\left.\mathrm{Y}_{3}\right)$ of the $\mathrm{BF}$. The regression coefficient of determination $\left(\mathrm{R}^{2}\right)$ and lack-of-fit value were determined to evaluate the fitness of the polynomial 
Table 2. Data obtained from the response surface methodology based on the central composite design (RSM-CCD)

\begin{tabular}{|c|c|c|c|c|c|c|c|c|c|}
\hline \multirow{3}{*}{ Run } & \multicolumn{3}{|c|}{ Independent Variables } & \multicolumn{6}{|c|}{ Response Variables* } \\
\hline & \multirow[t]{2}{*}{$\begin{array}{c}\mathrm{X}_{1} \\
\left({ }^{\circ} \mathrm{C}\right) \\
\end{array}$} & \multirow[t]{2}{*}{$\begin{array}{c}\mathrm{X}_{2} \\
(\mathrm{MPa}) \\
\end{array}$} & \multirow[t]{2}{*}{$\begin{array}{c}X_{3} \\
(\min )\end{array}$} & \multicolumn{2}{|c|}{$\begin{array}{c}Y_{1} \\
(\%)\end{array}$} & \multicolumn{2}{|c|}{$\begin{array}{c}Y_{2} \\
(\%) \\
\end{array}$} & \multicolumn{2}{|c|}{$\begin{array}{c}Y_{3} \\
(\%)\end{array}$} \\
\hline & & & & Experimental & Predicted & Experimental & Predicted & Experimental & Predicted \\
\hline 1 & 38 & 14 & 10 & 17.81 & 16.47 & 71.77 & 71.04 & 52.85 & 52.55 \\
\hline 2 & 54 & 14 & 10 & 16.62 & 17.65 & 71.01 & 70.96 & 51.76 & 51.83 \\
\hline 3 & 38 & 28 & 10 & 54.72 & 53.61 & 82.87 & 83.09 & 55.72 & 55.70 \\
\hline 4 & 54 & 28 & 10 & 34.99 & 38.18 & 78.67 & 78.94 & 55.48 & 55.62 \\
\hline 5 & 38 & 14 & 30 & 44.14 & 42.64 & 75.41 & 75.03 & 54.13 & 54.18 \\
\hline 6 & 54 & 14 & 30 & 41.14 & 43.93 & 79.31 & 78.98 & 54.38 & 54.59 \\
\hline 7 & 38 & 28 & 30 & $* * 82.70$ & 83.36 & $* * 86.57$ & 86.50 & 56.24 & 56.35 \\
\hline 8 & 54 & 28 & 30 & 65.00 & 68.03 & 85.77 & 86.38 & 56.91 & 57.40 \\
\hline 9 & 32.5 & 21 & 20 & 56.19 & 58.96 & 82.03 & 82.55 & 55.04 & 55.23 \\
\hline 10 & 60 & 21 & 20 & 52.23 & 47.07 & 82.74 & 82.39 & 55.96 & 55.51 \\
\hline 11 & 46 & 9.2 & 20 & 15.16 & 15.39 & 65.23 & 66.06 & 51.94 & 52.02 \\
\hline 12 & 46 & 32.8 & 20 & 69.51 & 66.89 & 83.09 & 82.42 & $* * 57.36$ & 57.02 \\
\hline 13 & 46 & 21 & 3.2 & 18.51 & 18.26 & 74.98 & 75.10 & 53.12 & 53.28 \\
\hline 14 & 46 & 21 & 36.8 & 67.52 & 65.37 & 84.66 & 84.71 & 56.56 & 56.14 \\
\hline 15 & 46 & 21 & 20 & 44.13 & 42.72 & 79.66 & 78.96 & 55.86 & 56.37 \\
\hline 16 & 46 & 21 & 20 & 40.57 & 42.72 & 78.61 & 78.96 & 56.80 & 56.37 \\
\hline 17 & 46 & 21 & 20 & 43.25 & 42.72 & 79.17 & 78.96 & 56.17 & 56.37 \\
\hline 18 & 46 & 21 & 20 & 47.87 & 42.72 & 79.72 & 78.96 & 56.81 & 56.37 \\
\hline 19 & 46 & 21 & 20 & 39.66 & 42.72 & 78.05 & 78.96 & 56.70 & 56.37 \\
\hline 20 & 46 & 21 & 20 & 40.41 & 42.72 & 78.58 & 78.96 & 55.80 & 56.37 \\
\hline
\end{tabular}

* $\mathrm{Y}_{1}=$ percentage of fat reduction; $\mathrm{Y}_{2}=$ percentage of cholesterol reduction; $\mathrm{Y}_{3}=$ lightness ( $\mathrm{L}^{*}$ value)

** The highest percentage of fat reduction (82.70\%), cholesterol reduction (86.57\%), and lightness (57.36) was obtained

equation to the response variables. Three-dimensional (3D) response surface plots and two-dimensional (2D) contour plots were generated to explain the effects of the independent variables on the response variables. The significance level of all the terms of the polynomial equation was analyzed statistically by computing the $\mathrm{p}$ value based on a confidence level of $95.0 \%$. The verification of model validity by comparing the experimental values with the predicted values of the optimized model was analyzed using t-test method in Statistical Package for the Social Sciences (SPSS) software (version 21). A significant difference was considered at the level of $\mathrm{p}<0.05$. The same statistical analysis was applied for chemical composition and colour characteristics of STBF and untreated BF.

\section{Results and discussion}

\subsection{Response Surface Model (RSM)}

3.1.1 Identifying $\mathrm{Sc}-\mathrm{CO}_{2}$ extraction conditions on the percentage of fat reduction, cholesterol reduction and lightness from beeffloss

Table 2 shows the full experimental design and corresponding data obtained. It was shown that the highest percentage of fat reduction $\left(\mathrm{Y}_{1}\right)$, cholesterol reduction $\left(\mathrm{Y}_{2}\right)$, and lightness $\left(\mathrm{Y}_{3}\right)$ was at the run number of 7, 7, and 12, respectively. The highest percentage of fat $(82.70 \%)$ and cholesterol $(86.57 \%)$ reduction was obtained at the temperature and pressure of $38^{\circ} \mathrm{C}$ and 28 $\mathrm{MPa}$, respectively, for $30 \mathrm{~min}$. In contrast, the most substantial lightness (57.36) was observed at the combined effect of $46^{\circ} \mathrm{C}, 32.8 \mathrm{MPa}$, and the extraction time of $20 \mathrm{~min}$. Generally, temperature and pressure are the most influencing factors for the solubility of lipids in Sc- $\mathrm{CO}_{2}$ (Sánchez-Camargo et al., 2017). This is likely due to an increase in $\mathrm{CO}_{2}$ density and hence lipid solubility in $\mathrm{Sc}_{-} \mathrm{CO}_{2}$ (Shao et al., 2014; SánchezCamargo et al., 2017), which was demonstrated in the extraction of lipid and cholesterol from the squid oil (Kang et al., 2005) and removal of cholesterol from cow brain (Vedaraman et al., 2005).

\subsubsection{Fitting the model and analysis of experimental design}

A CCD-RSM was performed to study the effects of three independent variables (temperature; $\mathrm{X}_{1}$, pressure; $\mathrm{X}_{2}$, and extraction time; $\mathrm{X}_{3}$ ) on the three response variables (percentage of fat reduction; $\mathrm{Y}_{1}$, cholesterol reduction; $\mathrm{Y}_{2}$, and lightness; $\mathrm{Y}_{3}$ ) from $\mathrm{BF}$. In the model, a smaller $p$-value and a larger regression coefficient determination $\left(\mathrm{R}^{2}\right)$ indicate a more significant influence on the respective response variables (Patel et al., 2011). From the ANOVA results, as shown in Table 3, the model was found to be highly significant, with a p-value of 0.000 for all the response variables $\left(\mathrm{Y}_{1}, \mathrm{Y}_{2}\right.$, and $\left.\mathrm{Y}_{3}\right)$. The $\mathrm{p}$-value can be categorized as: $\mathrm{p}<0.01=$ "highly 
Table 3. ANOVA of multiple regression models for the response variable.

\begin{tabular}{|c|c|c|c|c|c|}
\hline Source & $\begin{array}{l}\text { Degree of } \\
\text { freedom }\end{array}$ & $\begin{array}{l}\text { Adjusted sum of } \\
\text { square }\end{array}$ & $\begin{array}{c}\text { Adjusted mean } \\
\text { square }\end{array}$ & F-value & p-value \\
\hline \multicolumn{6}{|c|}{ Percentage of fat reduction $\left(\mathrm{R}^{2}=0.9804\right.$; Adjusted $\left.\mathrm{R}^{2}=0.9628\right)$} \\
\hline Regression & 9 & 6404.17 & 711.57 & 55.65 & $0.000 *$ \\
\hline Linear & 3 & 6051.11 & 2017.04 & 157.75 & $0.000 *$ \\
\hline Square (quadratic) & 3 & 208.54 & 69.51 & 5.44 & $0.0188^{*}$ \\
\hline Interaction & 3 & 144.52 & 48.17 & 3.77 & $0.048 * *$ \\
\hline Residual error & 10 & 127.86 & 12.79 & & \\
\hline Lack-of-Fit & 5 & 79.83 & 15.97 & 1.66 & $0.295^{\mathrm{ns}}$ \\
\hline Pure error & 5 & 48.04 & 9.61 & & \\
\hline Total & 19 & 6532.03 & & & \\
\hline \multicolumn{6}{|c|}{ Percentage of cholesterol reduction $\left(\mathrm{R}^{2}=0.9904 ;\right.$ Adjusted $\left.\mathrm{R}^{2}=0.9818\right)}$. \\
\hline Regression & 9 & 522.037 & 58.004 & 114.75 & $0.000^{*}$ \\
\hline Linear & 3 & 434.587 & 144.862 & 286.59 & $0.000^{*}$ \\
\hline Square (quadratic) & 3 & 70.899 & 23.633 & 46.75 & $0.000^{*}$ \\
\hline Interaction & 3 & 16.551 & 5.517 & 10.91 & $0.002 *$ \\
\hline Residual error & 10 & 5.055 & 0.505 & & \\
\hline Lack-of-Fit & 5 & 2.848 & 0.57 & 1.29 & $0.393^{\mathrm{ns}}$ \\
\hline Pure error & 5 & 2.207 & 0.441 & & \\
\hline Total & 19 & 527.092 & & & \\
\hline \multicolumn{6}{|c|}{ Lightness $\left(\mathrm{R}^{2}=0.9617\right.$; Adjusted $\left.\mathrm{R}^{2}=0.9273\right)$} \\
\hline Regression & 9 & 52.5773 & 5.8419 & 27.91 & $0.000 *$ \\
\hline Linear & 3 & 40.3042 & 13.4347 & 64.19 & $0.000 *$ \\
\hline Square (quadratic) & 3 & 10.9549 & 3.6516 & 17.45 & $0.000 *$ \\
\hline Interaction & 3 & 1.3182 & 0.4394 & 2.10 & $0.164^{\mathrm{ns}}$ \\
\hline Lack-of-Fit & 5 & 0.9683 & 0.1937 & 0.86 & $0.563^{\mathrm{ns}}$ \\
\hline Residual error & 10 & 2.0929 & 0.2093 & & \\
\hline Pure error & 5 & 1.1245 & 0.2249 & & \\
\hline Total & 19 & 54.6702 & & & \\
\hline
\end{tabular}

$* \mathrm{p}<0.01$ highly significant; $* * 0.01<\mathrm{p}<0.05$ significant; $\mathrm{ns}: 0.05<\mathrm{p}$ not significant.

significant", $0.01<p<0.05=$ "significant", and $0.05<p=$ "not significant" (Vatansever and Hall, 2020). Therefore, this study resulted in the largest effect on the independent variables to the response variables of the BF. The model also adequately represented the experimental values for all the response variables $\left(\mathrm{Y}_{1}\right.$, $\mathrm{Y}_{2}$, and $\mathrm{Y}_{3}$ ), resulting in high $\mathrm{R}^{2}$ of $0.9804,0.9904$, and 0.9617 , respectively. The closer the $\mathrm{R}^{2}$ value to one, the better is the fitting of the model with the actual data, and the better is the correlation between experimental and predicted values (Zaibunnisa et al., 2009). The fitness of the model was considered good as the predicted values of the response variables were found to be relatively in line with their experimental values (Dey Paul et al., 2016). Moreover, the small difference between $R^{2}$ and adjusted $\mathrm{R}^{2}$ indicates that the models are adequate to data (Patel et al., 2011). In this study, it was found that the adjusted $R^{2}$ was high and very close to the $R^{2}$. Respective values $\left(\mathrm{Y}_{1}, \mathrm{Y}_{2}\right.$, and $\left.\mathrm{Y}_{3}\right)$ for adjusted $\mathrm{R}^{2}$ were $0.9628,0.9818$, and 0.9273 . Thus, the high values of adjusted $\mathrm{R}^{2}$ and $\mathrm{R}^{2}$ indicate a high dependence and correlation between the experimental values and the predicted values of the response variables. Take the cholesterol reduction as an example; this implies that the sample variation of $99.04 \%$ could be attributable to the independent variables.

The adequacy of the model also can be revealed by using lack-of-fit. The findings of this study showed that the model predicted all the response variables $\left(\mathrm{Y}_{1}, \mathrm{Y}_{2}\right.$, and $\mathrm{Y}_{3}$ ) were satisfactory as indicated by error analysis showing non-significant lack-of-fit $(\mathrm{p}>0.05)$ with a $\mathrm{p}$ value of $0.295,0.393$, and 0.563 , respectively (Table 3 ).

The negligible p-value thus implies that the model is good and fits well with the experimental values. Overall, the high goodness of fit suggested that the predicted model was statistically valid, and feasibility of the polynomial equations was established. The second-order polynomial model equation is illustrated as follows:

$$
\begin{aligned}
\mathrm{Y}_{1}= & 37.2-4.12 \mathrm{X}_{1}+5.82 \mathrm{X}_{2}+1.244 \mathrm{X}_{3}+0.0569 \mathrm{X}_{1} \mathrm{X}_{1} \\
& -0.0113 \mathrm{X}_{2} \mathrm{X}_{2}-0.00318 \mathrm{X}_{3} \mathrm{X}_{3}-0.0742 \mathrm{X}_{1} \mathrm{X}_{2} \\
& +0.0003 \mathrm{X}_{1} \mathrm{X}_{3}+0.0128 \mathrm{X}_{2} \mathrm{X}_{3} \\
\mathrm{Y}_{2}= & 79.43-1.659 \mathrm{X}_{1}+3.001 \mathrm{X}_{2}-0.384 \mathrm{X}_{3} \\
& +0.01938 \mathrm{X}_{1} \mathrm{X}_{1}-0.03404 \mathrm{X}_{2} \mathrm{X}_{2}+0.00333 \mathrm{X}_{3} \mathrm{X}_{3}- \\
& 0.01817 \mathrm{X}_{1} \mathrm{X}_{2}+0.01258 \mathrm{X}_{1} \mathrm{X}_{3}-0.00204 \mathrm{X}_{2} \mathrm{X}_{3} \\
\mathrm{Y}_{3}= & 34.36+0.387 \mathrm{X}_{1}+0.712 \mathrm{X}_{2}+0.231 \mathrm{X}_{3}- \\
& 0.00551 \mathrm{X}_{1} \mathrm{X}_{1}-0.01333 \mathrm{X}_{2} \mathrm{X}_{2}-0.00586 \mathrm{X}_{3} \mathrm{X}_{3} \\
& +0.00285 \mathrm{X}_{1} \mathrm{X}_{2}+0.00352 \mathrm{X}_{1} \mathrm{X}_{3}-0.00350 \mathrm{X}_{2} \mathrm{X}_{3}
\end{aligned}
$$


where $\mathrm{X}_{1}$, temperature $\left({ }^{\circ} \mathrm{C}\right) ; \mathrm{X}_{2}$, pressure $(\mathrm{MPa})$ and $\mathrm{X}_{3}$, extraction time ( $\mathrm{min})$

\subsubsection{Response surface analysis of the optimum condition}

In this study, the optimum conditions of $\mathrm{Sc}-\mathrm{CO}_{2}$ extraction from the response surface were estimated and verified at $\mathrm{X}_{1}=51.0^{\circ} \mathrm{C}, \mathrm{X}_{2}=32.8 \mathrm{MPa}$, and $\mathrm{X}_{3}=32.7$ $\mathrm{min}$. The best way to visualize the effect of independent variables on the response variables is to draw surface response plots of the model (Xu et al., 2008). Figures 2ad, 3a-d, and 4a-d illustrate the 3D response surface plots and 2D contour plots for the effect of independent variables $\left(\mathrm{X}_{1}, \mathrm{X}_{2}\right.$, and $\left.\mathrm{X}_{3}\right)$ on the response variables $\left(\mathrm{Y}_{1}\right.$, $\mathrm{Y}_{2}$, and $\mathrm{Y}_{3}$ ). Figure $2 \mathrm{a}-\mathrm{b}, 3 \mathrm{a}-\mathrm{b}$, and $4 \mathrm{a}-\mathrm{b}$ demonstrated significant interactions between temperatures and extraction time at constant pressure on the $Y_{1}, Y_{2}$, and $Y_{3}$ of the BF, respectively. As can be seen in Figures $2 \mathrm{a}-\mathrm{b}$ and $3 a-b$, the percentage of fat reduction and cholesterol reduction is higher at temperatures below $50^{\circ} \mathrm{C}$ than that above $50^{\circ} \mathrm{C}$. A similar trend was also observed by Wehling et al. (1992), who reported that increasing the temperature from 45 to $55^{\circ} \mathrm{C}$ at the pressure of $23.4 \mathrm{MPa}$ increased the fat and cholesterol reduction in dehydrated cooked beef from 60 to $97.6 \%$ and 76.4 to $85.4 \%$, respectively. Also, Taher et al. (2011) reported that an increase in temperature from 35 to $45^{\circ} \mathrm{C}$ at a constant pressure of $30 \mathrm{MPa}$, increased percentage of fat extracted
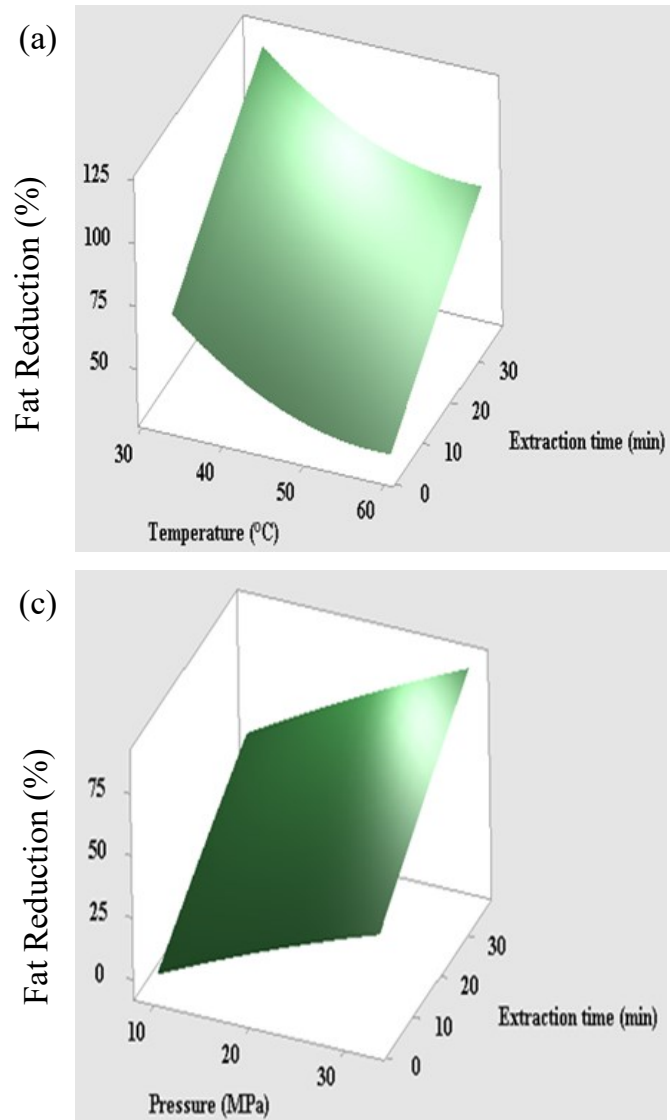

from lamb meat from 75 to $87 \%$, but further increase to $55^{\circ} \mathrm{C}$ reduced the fat removal to $65 \%$. This is due to the competing effect of solvation power of $\mathrm{CO}_{2}$ and volatility of fat with the temperature. At constant pressure, the density of $\mathrm{CO}_{2}$ decreases with an elevation of temperature but, at the same time, increases the volatility of the fat (Taher et al., 2011). Likewise, cholesterol solubility in $\mathrm{Sc}-\mathrm{CO}_{2}$ increases with the extraction temperature, which indicates that higher vapour pressure of $\mathrm{Sc}-\mathrm{CO}_{2}$ at elevated temperature has a more distinct impact than $\mathrm{Sc}-\mathrm{CO}_{2}$ density (Vedaraman et al., 2004). This was also demonstrated by Huang et al. (2004), who found that cholesterol solubility in $\mathrm{Sc}-\mathrm{CO}_{2}$ increased with an increase in temperature from 39.85 to $49.85^{\circ} \mathrm{C}$ at a constant pressure of $24 \mathrm{MPa}$. Figure $4 \mathrm{a}-\mathrm{b}$ illustrated the increase in lightness as the temperature increased from 30.0 to $51.0^{\circ} \mathrm{C}$ at a constant pressure of $32.8 \mathrm{MPa}$. Higher lightness ( $\mathrm{L}^{*}$ value) implies the pale appearance of the $\mathrm{Sc}-\mathrm{CO}_{2}$ extracted meat samples (González-Alonso et al., 2020). This study shows the increase in the lightness of BF could be due to the reduction of fat-soluble pigments such as carotenoids and diarylheptanoids from the added spices in BF that were carried away by the extracted oil. Similarly, Lin et al. (1999) reported that the lightness of pork floss increased from 45.2 to 72.2 as temperature increased from 50 to $150^{\circ} \mathrm{C}$ at $34.5 \mathrm{MPa}$ in $20 \mathrm{~min}$. They claimed it might be due to the partial removal of added soy sauce

(b)

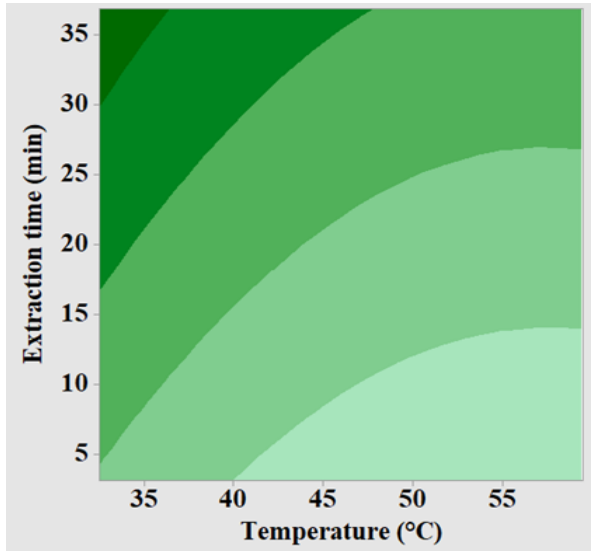

(d)

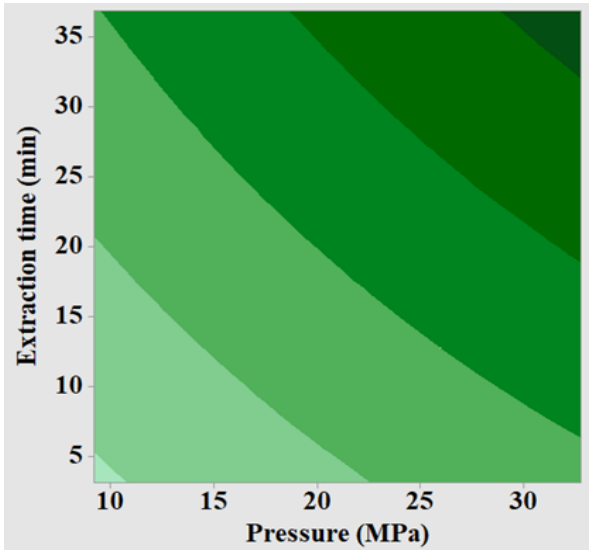

Figure 2. Response surfaces and contour plots for: $(\mathrm{a}, \mathrm{b})$ temperature, $\mathrm{X}_{1}: 51.0^{\circ} \mathrm{C}$ and extraction time, $\mathrm{X}_{3}: 32.7$ min $($ constant value pressure, $\mathrm{X}_{2}: 32.8 \mathrm{MPa}$ ); $(\mathrm{c}, \mathrm{d})$ pressure, $\mathrm{X}_{2}: 32.8 \mathrm{MPa}$ and extraction time, $\mathrm{X}_{3}: 32.7$ mins (constant value temperature, $\mathrm{X}_{1}$ : $51.0^{\circ} \mathrm{C}$ ) for percentage fat reduction $(\%)$ 


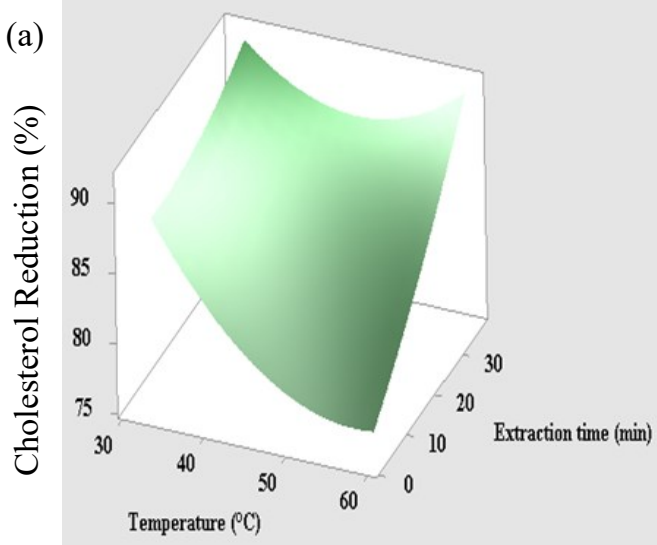

(b)
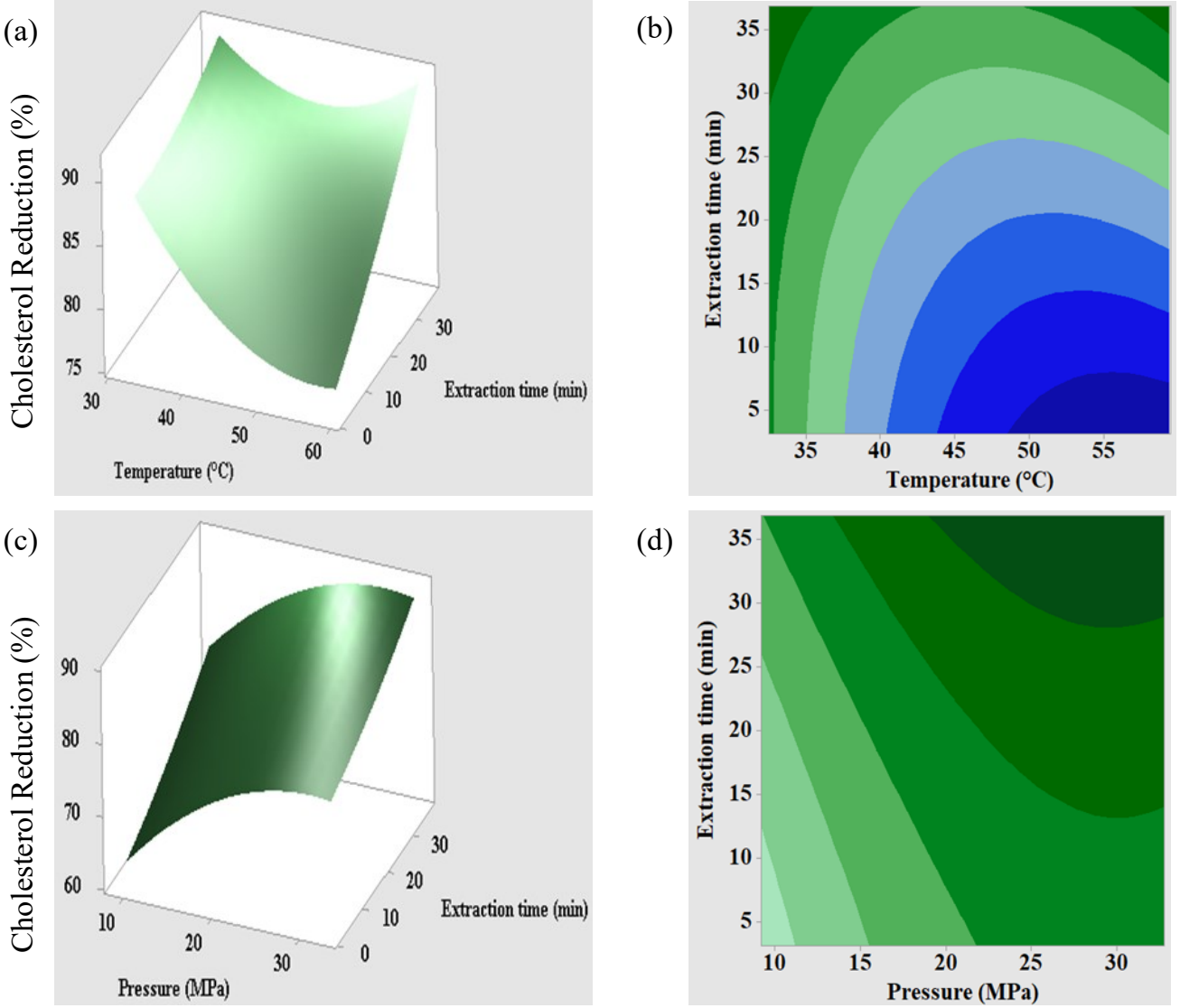

(d)

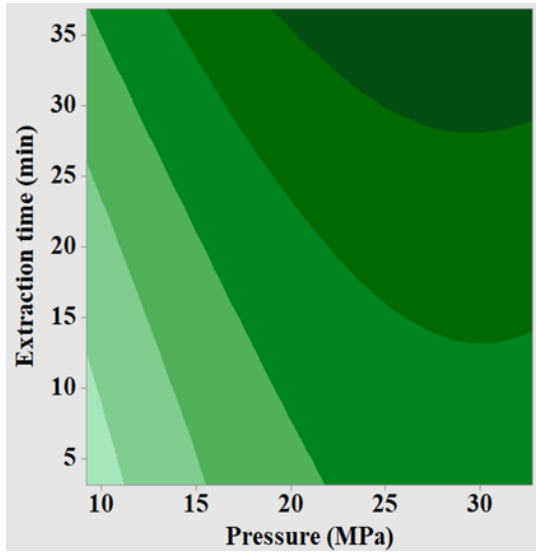

Figure 3. Response surfaces and contour plots for: $(\mathrm{a}, \mathrm{b})$ temperature, $\mathrm{X}_{1}: 51.0^{\circ} \mathrm{C}$ and extraction time, $\mathrm{X}_{3}: 32.7$ mins $($ constant value pressure, $\left.\mathrm{X}_{2}: 32.8 \mathrm{MPa}\right) ;(\mathrm{c}, \mathrm{d})$ pressure, $\mathrm{X}_{2}: 32.8 \mathrm{MPa}$ and extraction time, $\mathrm{X}_{3}: 32.7$ mins (constant value temperature, $\mathrm{X}_{1}$ : $\left.51.0^{\circ} \mathrm{C}\right)$ for percentage cholesterol reduction $(\%)$

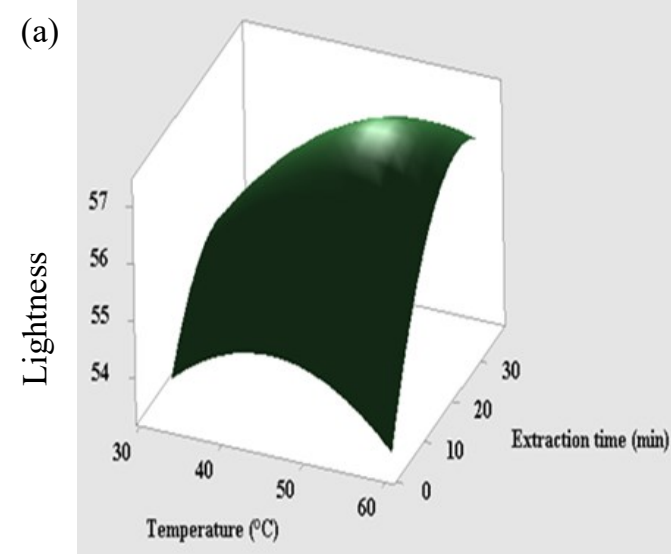

(b)
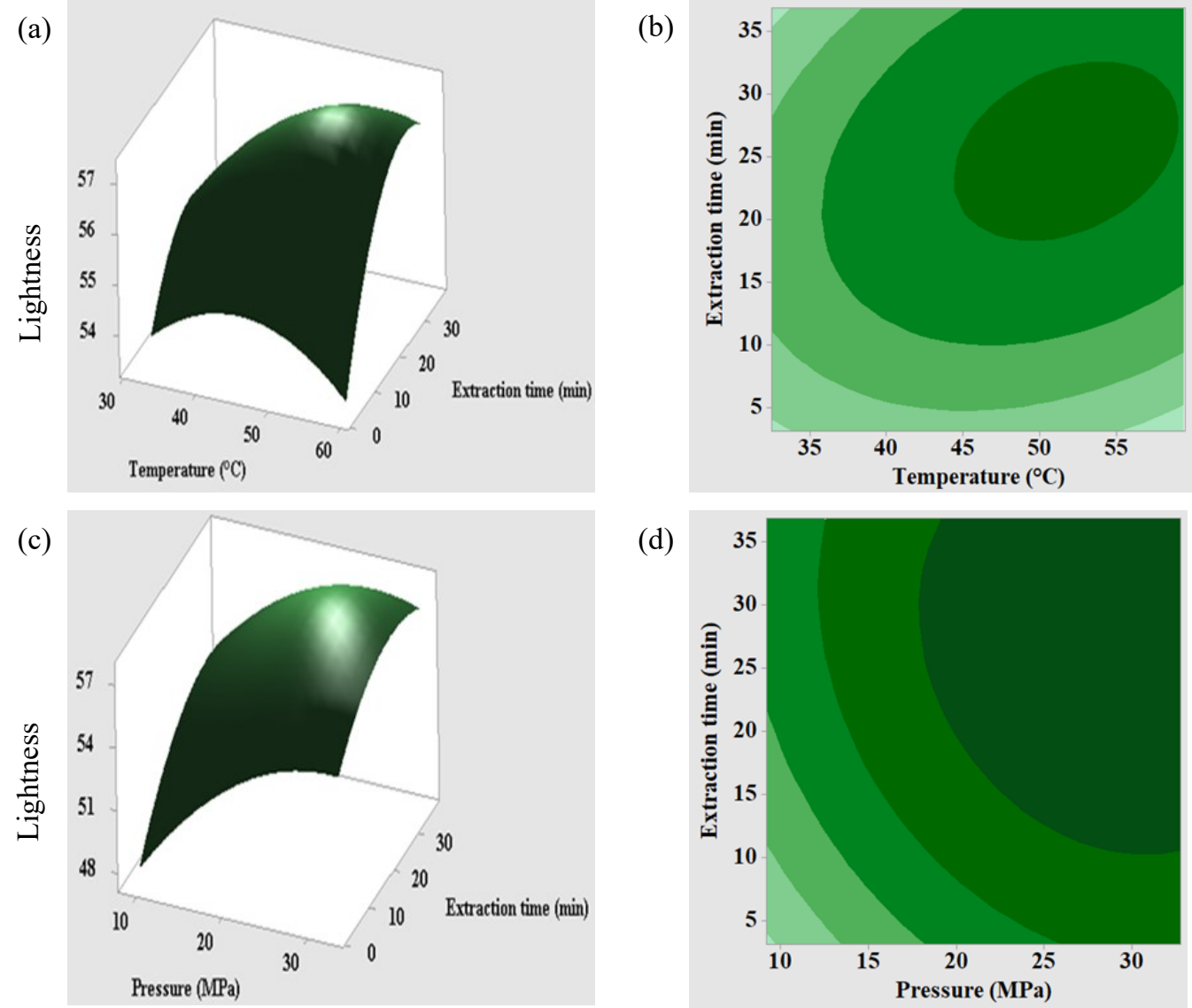

(d)

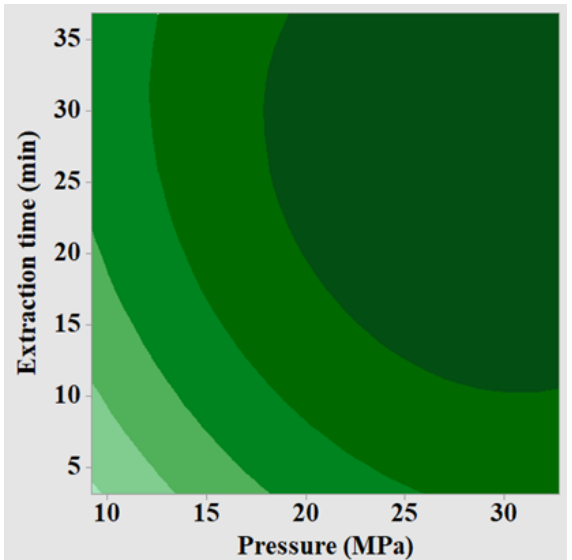

Figure 4. Response surfaces and contour plots for: $(\mathrm{a}, \mathrm{b})$ temperature, $\mathrm{X}_{1}: 51.0^{\circ} \mathrm{C}$ and extraction time, $\mathrm{X}_{3}: 32.7$ mins $($ constant value pressure, $\mathrm{X}_{2}: 32.8 \mathrm{MPa}$ ); $(\mathrm{c}, \mathrm{d})$ pressure, $\mathrm{X}_{2}: 32.8 \mathrm{MPa}$ and extraction time, $\mathrm{X}_{3}: 32.7$ mins (constant value temperature, $\mathrm{X}_{1}$ : $51.0^{\circ} \mathrm{C}$ ) for lightness 
in the product formulation that contributes to the darkness of the pork floss (Lin et al., 1999).

Figures $2 \mathrm{c}-\mathrm{d}, 3 \mathrm{c}-\mathrm{d}$, and $4 \mathrm{c}-\mathrm{d}$ illustrated $3 \mathrm{D}$ response surface and 2D contour plot on the effect of pressure $\left(\mathrm{X}_{2}\right)$ and extraction time $\left(\mathrm{X}_{3}\right)$ at a constant temperature of $51{ }^{\circ} \mathrm{C}$ for all the response variables $\left(\mathrm{Y}_{1}, \mathrm{Y}_{2}\right.$, and $\left.\mathrm{Y}_{3}\right)$. As shown in Figure $2 \mathrm{c}-\mathrm{d}, 3 \mathrm{c}-\mathrm{d}$, the percentage of fat reduction and cholesterol reduction increased significantly $(\mathrm{p}<0.05)$ with an increase in pressure. A similar pattern was reported by Chao et al. (1991), who indicated that the higher pressure of $31 \mathrm{MPa}$ was more effective than $17.2 \mathrm{MPa}$ at $50^{\circ} \mathrm{C}$ in order to achieve $71.2 \%$ and $39.8 \%$ reduction in fat and cholesterol from ground beef, respectively. Chitra et al. (2015) reported a $55.8 \%$ reduction of cholesterol from milk powder at the optimized condition of $68^{\circ} \mathrm{C}, 20.7 \mathrm{MPa}$ for $40 \mathrm{~min}$. They also reported an increase in the density of $\mathrm{Sc}-\mathrm{CO}_{2}$ as the pressure increased from 15 to $25 \mathrm{MPa}$ at $55^{\circ} \mathrm{C}$. In principle, the increase in extraction pressure at constant temperature increases the density and solvation power of $\mathrm{CO}_{2}$, which improves the solubility of lipids in $\mathrm{Sc}-\mathrm{CO}_{2}$ (Huang et al., 2004; Vedaraman et al., 2004; Ghasemi et al., 2011; Zaidul et al., 2012; Chitra et al., 2015; Dey Paul et al., 2016). The lightness also increased with the increase in pressure, as shown in Figures 4c-d. Carlez et al. (1995) reported that high pressure leads to an increase in the lightness of minced beef due to the denaturation of myoglobin as well as the coagulation of myofibrillar proteins. Also, Dey Paul et al. (2016) found that the lightness of milk powder was increased linearly with pressure from 17 to $23 \mathrm{MPa}$ at $48^{\circ} \mathrm{C}$, which is due to the removal of fat and fat-soluble pigments of the milk (Dey Paul et al., 2016).

Extraction time was also reported in various studies as an important factor for $\mathrm{Sc}-\mathrm{CO}_{2}$ extraction efficiency (Liu et al., 2009; Ghasemi et al., 2011; Pourmortazavi et al., 2018). As shown in Figure 2a,c, 3a,c and 4a,c, the response surface for all the response variables sharply increased with time from 3.2 min $\left(\mathrm{Y}_{1}=18.51 \%, \mathrm{Y}_{2}=\right.$ $74.98 \%$, and $\left.\mathrm{Y}_{3}=53.12\right)$ to $32.7 \mathrm{~min}\left(\mathrm{Y}_{1}=81.12 \%, \mathrm{Y}_{2}=\right.$ $86.17 \%$, and $\left.\mathrm{Y}_{3}=57.60\right)$. Similarly, Hou et al. (2010) found that the extraction time had a significant influence on the extraction yields of fat and cholesterol from goat placenta from $9.6 \mathrm{~min}$ to the optimum time of $29.1 \mathrm{~min}$. It is noteworthy that the amount of oil collected increased with the extraction time in this study. The increase in the amount of oil also resulted in the increased removal of fat-soluble pigments from the spices in BF, as previously explained. This is reflected by the reduced lightness of dried samples over time. This is in agreement with Lin et al. (1999), who reported the increased lightness of pork floss with an increase in fat and cholesterol reduction. Also, Markom and Singh
(2002) reported that the amount of palm oil and its colour intensity increased as the extraction progressed to $50^{\circ} \mathrm{C}$ and $20 \mathrm{MPa}$.

\subsubsection{Optimization of $\mathrm{Sc}-\mathrm{CO}_{2}$ extraction conditions and validation of models}

The response variables $Y_{1}, Y_{2}$, and $Y_{3}$ were validated using the estimated optimal conditions $\left(\mathrm{X}_{1} ; 51.0^{\circ} \mathrm{C}, \mathrm{X}_{2}\right.$; $32.8 \mathrm{MPa}$ and $\mathrm{X}_{3} ; 32.7 \mathrm{~min}$ ). As shown in Table 4 , the experimental results of $\mathrm{Y}_{1}, \mathrm{Y}_{2}$, and $\mathrm{Y}_{3}$ are $81.12 \pm 0.60 \%$, $86.17 \pm 0.33 \%$, and $57.60 \pm 0.47$, while the model predicted results were $80.98 \%, 86.49 \%$ and 56.94 , respectively. This is almost identical to that of Taher et al. (2011), who reported that $87.4 \%$ of fat content was extracted from lamb meat under the optimized conditions of $45^{\circ} \mathrm{C}$ and $50 \mathrm{MPa}$. However, Hou et al. (2010) reported that lipid yields from goat placenta were predicted to be only $21.02 \%$, at $35.3^{\circ} \mathrm{C}$ and $34.6 \mathrm{MPa}$ for 29.1 mins. It was shown in Table 4 that there was no significant difference $(p>0.05)$ between the experimental and predicted values for all the response variables, proving the accuracy of the regression model developed. Therefore, it was indicated that the models were sufficient to predict the response variables and confirmed the validity and adequacy of the final reduced model fitted by RSM.

Table 4. Comparison between the experimental and predicted values of response variables under the optimal $\mathrm{Sc}-\mathrm{CO}_{2}$ condition $\left(51.0^{\circ} \mathrm{C}, 32.8 \mathrm{MPa}\right.$, and $\left.32.7 \mathrm{mins}\right)$ for validation of model constructed

\begin{tabular}{lccc}
\hline \multicolumn{1}{c}{ Responses } & $\begin{array}{c}\text { Experimental } \\
\text { values }\end{array}$ & $\begin{array}{c}\text { Predicted } \\
\text { values }\end{array}$ & p-value \\
\hline Fat reduction (\%) & $81.12 \pm 0.60$ & 80.98 & 0.674 \\
Cholesterol reduction (\%) & $86.17 \pm 0.33$ & 86.49 & 0.142 \\
Lightness (L* value) & $57.60 \pm 0.47$ & 56.94 & 0.069 \\
\hline
\end{tabular}

Data are presented as mean \pm standard deviation $(n=4)$. Means between experimental and predicted values are not significantly different $(\mathrm{p}>0.05)$ for all responses.

\subsection{Chemical composition and colour characteristic of untreated and $\mathrm{Sc}-\mathrm{CO}_{2}$-treated $\mathrm{BF}$ (STBF)}

Table 5 presents the chemical composition and colour characteristic of untreated $\mathrm{BF}$ and STBF using the optimized conditions of $\mathrm{Sc}-\mathrm{CO}_{2}$ at $51.0^{\circ} \mathrm{C}$ and $32.8 \mathrm{MPa}$ for 32.7 mins. The results revealed significant differences $(p<0.05)$ in the percentage of moisture, ash, protein, fat, and cholesterol content between untreated BF and STBF. The fat content of STBF was $3.50 \%$, an $81.12 \%$ reduction from that of untreated BF (18.54\%). This almost achieved the criteria for making a 'low-fat' claim, which is $3 \%$ of fat content, as stipulated in the Malaysian Guide to Nutrition Labelling and Claims (National Coordinating Committee on Food and Nutrition, Ministry of Health Malaysia , 2010). Also, the 


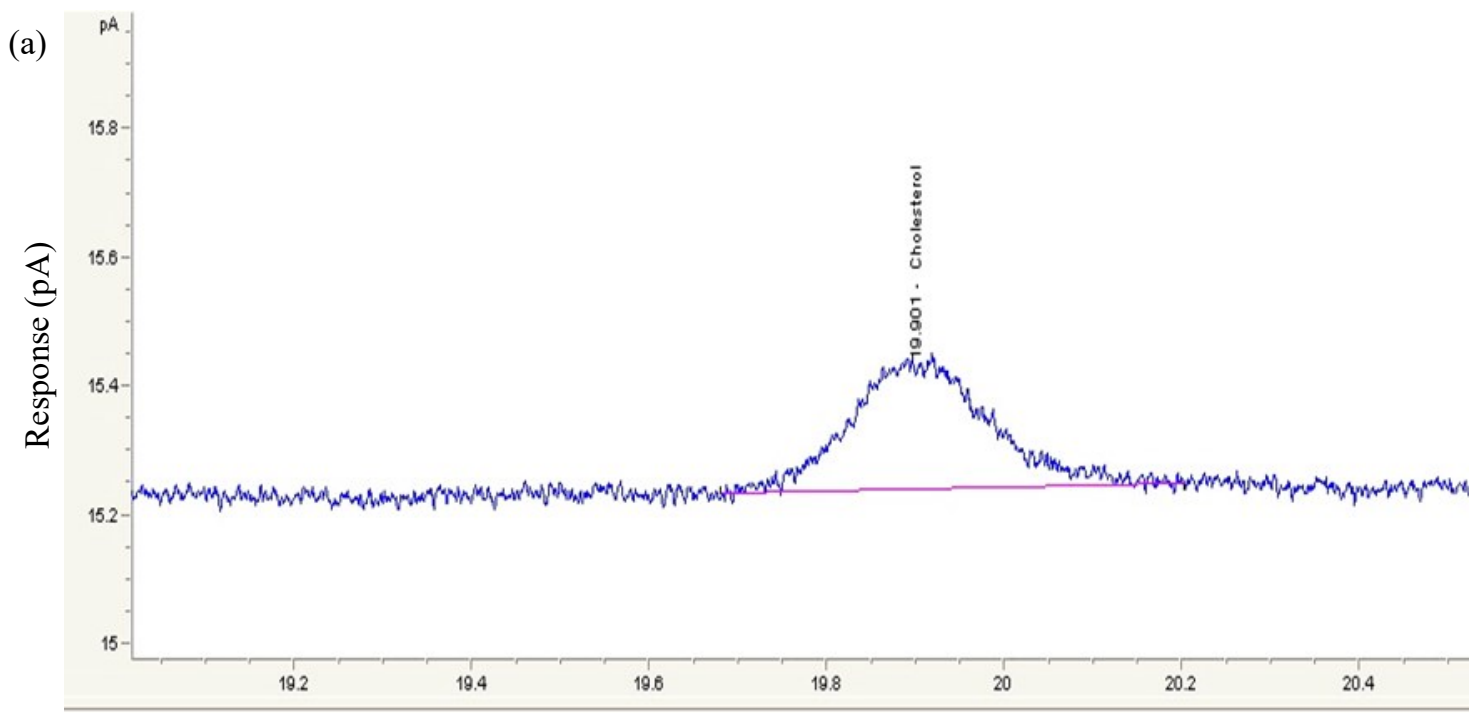

Retention time (min)

(b)

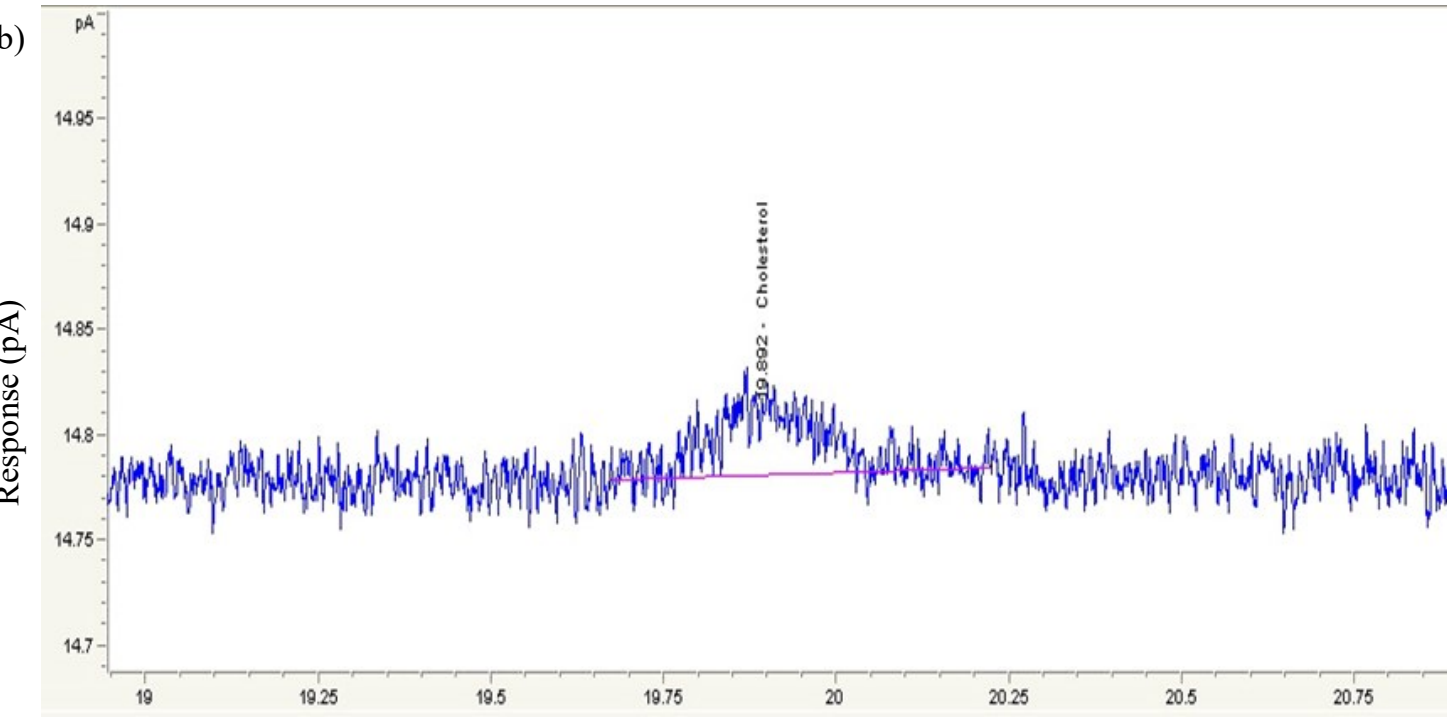

Retention time (min)

Figure 5. The GC-FID chromatograms of the cholesterol peak for (a) untreated beef floss (BF) and (b) supercritical carbon dioxide treated beef floss (STBF) samples.

Table 5. Chemical composition and colour characteristic of untreated beef floss (BF) and $\mathrm{Sc}-\mathrm{CO}_{2}$-treated beef floss (STBF)

\begin{tabular}{lcc}
\hline Chemical composition $(\mathrm{g} / 100 \mathrm{~g})$ & Untreated BF & $\mathrm{STBF}^{\mathrm{l}}$ \\
\hline Moisture & $10.71 \pm 0.12^{\mathrm{a}}$ & $6.69 \pm 0.17^{\mathrm{b}}$ \\
Ash & $4.88 \pm 0.04^{\mathrm{a}}$ & $7.08 \pm 0.13^{\mathrm{b}}$ \\
Protein & $28.84 \pm 0.04^{\mathrm{a}}$ & $42.25 \pm 0.43^{\mathrm{b}}$ \\
Fat & $18.54 \pm 0.16^{\mathrm{a}}$ & $3.50 \pm 0.11^{\mathrm{b}}$ \\
Cholesterol (mg/100 g) & $90.69 \pm 1.80^{\mathrm{a}}$ & $12.55 \pm 0.33^{\mathrm{b}}$ \\
\hline Colour characteristic & & \\
\hline$L^{*}$ & $51.09 \pm 0.52^{\mathrm{a}}$ & $57.60 \pm 0.47^{\mathrm{b}}$ \\
$a^{*}$ & $10.09 \pm 0.76^{\mathrm{a}}$ & $10.70 \pm 0.23^{\mathrm{a}}$ \\
$b^{*}$ & $18.63 \pm 1.54^{\mathrm{a}}$ & $23.51 \pm 0.40^{\mathrm{b}}$ \\
\hline
\end{tabular}

Data are presented as means \pm standard deviation $(n=4)$.

Means with different lower-case superscripts in the same row are significantly different $(\mathrm{p}<0.05)$.

${ }^{1}$ Under the optimal $\mathrm{Sc}-\mathrm{CO}_{2}$ condition of $51.0^{\circ} \mathrm{C}, 32.8 \mathrm{MPa}$ and 32.7 mins. cholesterol content of STBF was $12.55 \mathrm{mg} / 100 \mathrm{~g}$, an $86.17 \%$ reduction from that of untreated $\mathrm{BF}(90.69$ $\mathrm{mg} / 100 \mathrm{~g})$. Figure $5 \mathrm{a}-\mathrm{b}$ presented the chromatograms of the cholesterol peak obtained from the untreated BF and STBF at the retention time of 19.91 mins. It shows the cholesterol peak area for STBF (Figure 5b) was smaller than that for the untreated BF (Figure 5a), indicating $86.17 \%$ reduction. Although high reduction was observed, the cholesterol content of STBF (12.55 $\mathrm{mg} / 100 \mathrm{~g}$ ) is still greater than $2 \mathrm{mg} / 100 \mathrm{~g}$, the maximum requirement for a low cholesterol food product claim as stipulated by the Malaysian Guide to Nutrition Labelling and Claims (National Coordinating Committee on Food and Nutrition, Ministry of Health Malaysia, 2010). Froning et al. (1994) reported $95 \%$ and $89 \%$ of fat and cholesterol were extracted from dehydrated cooked chicken at $55^{\circ} \mathrm{C}$ and $38.6 \mathrm{MPa}$. However, Lin et al. (1999) reported only $30.7 \%$ and $50.5 \%$ reduction of fat and cholesterol from pork floss following a 20 mins Sc$\mathrm{CO}_{2}$ treatment at $50^{\circ} \mathrm{C}$ and $34.5 \mathrm{MPa}$. Their extraction 
time may not be sufficient as prolonged duration of Sc$\mathrm{CO}_{2}$ exposure potentially leads to an increase in the extraction yields (Bogdanovic et al., 2016). This is further supported by Pourmortazavi et al. (2019), who stated that time is one of the most important factors and proposed RSM for the optimization of $\mathrm{Sc}-\mathrm{CO}_{2}$-based extraction in foodstuffs (Pourmortazavi et al., 2019). The moisture content of STBF $(6.69 \%)$ was significantly $(p<0.05)$ decreased by $37.5 \%$ from that of untreated BF (10.71\%). Wehling et al. (1992) and Froning et al. (1994) also reported a decrease in the moisture content by $70.1 \%$ and $57.2 \%$ from dehydrated beef and chicken meat, respectively, at $55^{\circ} \mathrm{C}$ and $38.6 \mathrm{MPa}$. $\mathrm{Sc}-\mathrm{CO}_{2}$ extraction reduced the moisture content in the treated samples as a result of increased pressure and temperature (Rahman et al., 2019). During the treatment, it was proposed that the $\mathrm{CO}_{2}$ enters the product being dried and carries away some water upon exiting (Brown et al., 2008). However, Lin et al. (1999) found that an insignificant reduction in moisture content between untreated and treated pork floss at $50^{\circ} \mathrm{C}$ and $34.5 \mathrm{MPa}$ for 20 mins. The high content of ash is due to the presence of minerals in the meat, and the addition of different spices in the preparation of meat floss (Ogunsola and Omojola, 2008). As shown in Table 5, the ash content of STBF was significantly $(\mathrm{p}<0.05)$ increased from 4.88 to $7.08 \%$ following the $\mathrm{Sc}-\mathrm{CO}_{2}$ extraction of fat and cholesterol. The protein content of STBF $(42.25 \%)$ was significantly $(\mathrm{p}<0.05)$ higher than untreated BF (28.84\%), amounting to a $46 \%$ increase. The result showed that reductions in moisture content previously explained led to increased dry matter and thus, the elevated protein content of the STBF. Similarly, an increase in protein content was also reported in dehydrated cooked beef (Wehling et al., 1992) and chicken (Froning et al., 1994) by $47 \%$ and $43 \%$, respectively, at $55^{\circ} \mathrm{C}$ and $38.6 \mathrm{MPa}$. Also, Kang et al. (2017) reported a $24 \%$ increase in protein content in the $\mathrm{Sc}-\mathrm{CO}_{2}$ treated defatted bovine liver at $45^{\circ} \mathrm{C}$ and 45 $\mathrm{MPa}$.

The variation of colour in $\mathrm{BF}$ is due to the differences in the formulations used and the preparation method (Huda et al., 2012). In this regard, there is no standard colour of BF in Malaysia (Sukisman et al., 2014), although the desirable colour could be described as golden-brown. The STBF (Figure 6b) under the optimum conditions was lighter than the untreated BF (Figure $6 \mathrm{a})$, in which the $\mathrm{L}^{*}$ (lightness), $\mathrm{a}^{*}$ (redness), and $\mathrm{b}^{*}$ (yellowness) values were $57.60 \pm 0.47,10.70 \pm 0.23$ and $23.51 \pm 0.40$, respectively (Table 5). However, this study shows there was no significant difference $(p>0.05)$ in the $\mathrm{a}^{*}$ values between untreated $\mathrm{BF}$ and STBF, indicating that the optimized conditions did not alter the redness of the STBF. Chitra et al. (2015) also reported the effect of
$\mathrm{Sc}-\mathrm{CO}_{2}$ on $\mathrm{L}^{*}, \mathrm{a}^{*}$, and $\mathrm{b}^{*}$ values of milk powder, which resulted in lighter milk powder with less $a^{*}$ and $b^{*}$ values. It was claimed that the reduced $a^{*}$ and $b^{*}$ values were attributed to the removal of $\beta$-carotene and carotenoid pigments along with lipids due to $\mathrm{Sc}-\mathrm{CO}_{2}$ extraction (Chitra et al., 2015). Total colour difference, $\Delta E$, representing an overall colour difference of STBF from the untreated BF was presented in Table 5. Based on Cserhalmi et al. (2006), $\Delta E$ can be classified as: 0 to $0.5=$ "not noticeable", 0.5 to $1.5=$ "slightly noticeable", and $>1.5=$ "noticeable". The $\Delta E$ value of SBTF was 8.16 , suggesting that the $\mathrm{Sc}-\mathrm{CO}_{2}$ application resulted in noticeable instrumental colour differences in BF. (a)

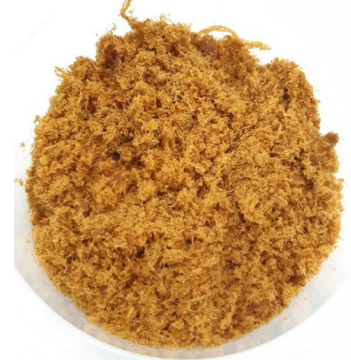

(b)

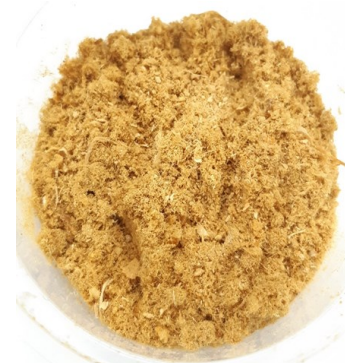

Figure 6. Photograph of (a) untreated beef floss (BF) and (b) supercritical carbon dioxide treated beef floss (STBF) samples.

\section{Conclusion}

A CCD-RSM was successfully employed to optimize $\mathrm{Sc}-\mathrm{CO}_{2}$ conditions, which include temperature, pressure, and extraction time as the independent variables for the response variables such as percentage of fat and cholesterol reduction as well as lightness from $\mathrm{BF}$. The high regression coefficients of the second-order polynomial indicated that the model was well fitted to the experimental values. RSM demonstrated that the independent variables have a significant influence on all the response variables, and predicted the optimum Sc$\mathrm{CO}_{2}$ conditions were found to be at $51.0^{\circ} \mathrm{C}, 32.8 \mathrm{MPa}$, and 32.7 mins. At this condition, the experimental values of fat reduction (\%), cholesterol reduction (\%), and lightness were $81.12 \%, 86.17 \%$, and 57.60 , respectively. The analysis of t-test showed that there was no significant difference $(p>0.05)$ between the mean of experimental and predicted values for all the response variables. Overall, $\mathrm{Sc}-\mathrm{CO}_{2}$ extraction was experimentally proven to be a feasible technique for its relatively short time to produce low fat and low cholesterol BF, with reduced moisture and elevated protein content.

\section{Conflict of interest}

This study has no conflict of interest.

\section{Acknowledgements}

The authors gratefully acknowledge Universiti Teknologi MARA, Shah Alam, Selangor, Malaysia, for 
funding this study (600-IRMI/MyRA 5/3/LESTARI (100/2017). The authors wish to thank the DirectorGeneral of Health Malaysia for permission to publish this paper. Sincere gratitude is also dedicated to the Food Safety and Quality Division and National Public Health Laboratory, Ministry of Health, Malaysia, for the laboratory facility and technical support.

\section{References}

AOAC. (2000). Official methods of analysis of AOAC International. 17th ed. Gaithersburg, MD, USA: AOAC.

Bogdanovic, A., Tadic, V., Stamenic, M., Petrovic, S. and Skala, D. (2016). Supercritical carbon dioxide extraction of Trigonella foenum-graecum L. seeds: Process optimization using response surface methodology. Journal of Supercritical Fluids, 107, 44-50. https://doi.org/10.1016/j.supflu.2015.08.003.

Bradley, R.L. (2010). Removal of cholesterol from milk fat using supercritical carbon dioxide. Journal of Dairy Science, 72(10), 2834-2840. https:// doi.org/10.3168/jds.s0022-0302(89)79429-7.

Brown, Z.K., Fryer, P.J., Norton, I.T., Bakalis, S. and Bridson, R.H. (2008). Drying of foods using supercritical carbon dioxide - Investigations with carrot. Innovative Food Science and Emerging Technologies, 9(3), 280-289. https://doi.org/10.1016/ j.ifset.2007.07.003.

Budisa, N. and Schulze-Makuch, D. (2014). Supercritical carbon dioxide and its potential as a life-sustaining solvent in a planetary environment. Life, 4(3), 331340. https://doi.org/10.3390/life4030331

Carlez, A., Veciana-Nogues, T. and Cheftel, J.C. (1995). Changes in colour and myoglobin of minced beef meat due to high pressure processing. LWT-Food Science and Technology, 28(5), 528-538. https:// doi.org/10.1006/fstl.1995.0088.

Chao, R.R., Mulvaney, S.J., Bailey, M.E. and Fernando, L.N. (1991). Supercritical CO2 conditions affecting extraction of lipid and cholesterol from ground beef. Journal of Food Science, 56(1), 183-187. https://doi.org/10.1111/j.1365-2621.1991.tb08007.x.

Chapkin, R.S (2007). Reappraisal of the essential fatty acids. In Chow, C.K. (Ed.), Fatty Acids in Foods and Their Health Implications, p. 675-691. USA: CRC Press. https://doi.org/10.1201/9781420006902.ch26

Chitra, J., Deb, S. and Mishra, H.N. (2015). Selective fractionation of cholesterol from whole milk powder: optimisation of supercritical process conditions. International Journal of Food Science and Technology, 50(11), 2467-2474. https:// doi.org/10.1111/ijfs.12914.

Chugh, A., Khanal, D., Walkling-Ribeiro, M., Corredig,
M., Duizer, L. and Griffiths, M.W. (2014). Change in colour and volatile composition of skim milk processed with pulsed electric field and microfiltration treatments or heat pasteurization. Foods, 3(2), 250-268. https://doi.org/10.3390/ foods3020250.

Cserhalmi, Z., Sass-Kiss, A., Tóth-Markus, M. and Lechner, N. (2006). Study of pulsed electric field treated citrus juices. Innovative Food Science and Emerging Technologies, 7(1-2), 49-54. https:// doi.org/10.1016/j.ifset.2005.07.001.

Darani, K.K. and Mozafari, M.R. (2010). Supercritical fluids technology in bioprocess industries : A review. Journal of Biochemical Technology, 2(1), 144-152.

Dey Paul, I., Jayakumar, C. and Niwas Mishra, H. (2016). Optimization of process parameters for supercritical fluid extraction of cholesterol from whole milk powder using ethanol as co-solvent. Journal of the Science of Food and Agriculture, 96 (15), 4885-4895. https://doi.org/10.1002/jsfa.7760.

Dinh, T.T.N., Thompson, L.D., Galyean, M.L., Brooks, J.C.L. and Boylan, M.L. (2012). Determination of total cholesterol in meat and poultry by gas Chromatography: Single-Laboratory validation. Journal of AOAC International, 95(2), 472-488. https://doi.org/10.5740/jaoacint.11-224.

Froning, G.W., Fieman, F., Wehling, R.L., Cuppett, S.L. and Niemann, L. (1994). Supercritical carbon dioxide extraction of lipids and cholesterol from dehydrated chicken meat. Poultry Science, 73(4), 571-575. https://doi.org/10.3382/ps.0730571.

Froning, G.W., Wehling, R.L., Cuppett, S. and Niemann, L. (1998). Moisture content and particle size of dehydrated egg yolk affect lipid and cholesterol extraction using supercritical carbon dioxide. Poultry Science, 77(11), 1718-1722. https://doi.org/10.1093/ ps/77.11.1718.

Ghasemi, E., Raofie, F. and Najafi, N.M. (2011). Application of response surface methodology and central composite design for the optimisation of supercritical fluid extraction of essential oils from Myrtus communis L. leaves. Food Chemistry, 126 (3), 1449-1453. https://doi.org/10.1016/ j.foodchem.2010.11.135.

González-Alonso, V., Cappelletti, M., Bertolini, F.M., Lomolino, G., Zambon, A. and Spilimbergo, S. (2020). Research Note: Microbial inactivation of raw chicken meat by supercritical carbon dioxide treatment alone and in combination with fresh culinary herbs. Poultry Science, 99(1), 536-545. https://doi.org/10.3382/ps/pez563.

Higuera-Ciapara, I., Toledo-Guillen, A.R., Noriega- 
Orozco, L., Martinez-Robinson, K.G. and EsquedaValle, M.C. (2005). Production of a low-cholesterol shrimp using supercritical extraction. Journal of Food Process Engineering, 28(5), 526-538. https:// doi.org/10.1111/j.1745-4530.2005.00038.x.

Hou, Z., Zheng, Y., Gao, Y., Liu, X., Yuan, F. and Liu, G. (2010). Optimization of supercritical carbon dioxide removal of lipid and cholesterol from goat placenta using response surface methodology. Food and Bioproducts Processing, 88(2-3), 298-304. https://doi.org/10.1016/j.fbp.2009.12.001.

Hu, J. and Deng, W. (2016). Application of supercritical carbon dioxide for leather processing. Journal of Cleaner Production, 113, 931-946. https:// doi.org/10.1016/j.jclepro.2015.10.104.

Huang, Z., Kawi, S. and Chiew, Y.C. (2004). Solubility of cholesterol and its esters in supercritical carbon dioxide with and without cosolvents. The Journal of Supercritical Fluids, 30(1), 25-39. https:// doi.org/10.1016/S0896-8446(03)00116-5.

Huda, N., Fatma, Y., Fazillah, A. and Adzitey, F. (2012). Chemical composition, colour and sensory characteristics of commercial serunding (Shredded meat) in Malaysia. Pakistan Journal of Nutrition, 11 (1), 1-4. https://doi.org/10.3923/pjn.2012.1.4.

Kang, K.Y., Ahn, D.H., Wilkinson, G.T. and Chun, B.S. (2005). Extraction of lipids and cholesterol from squid oil with supercritical carbon dioxide. Korean Journal of Chemical Engineering, 22(3), 399-405. https://doi.org/10.1007/BF02719418.

Kang, S.W., Kim, H.M, Rahman, M.S., Kim, A.N. and Yang, H. (2017). Nutritional quality and physicochemical characteristics of defatted bovine liver treated by supercritical carbon dioxide and organic solvent. Korean Journal for Food Science of Animal Resources, 37(1), 29. http://doi: 10.5851/ kosfa.2017.37.1.29.

Kumar, M., Nagpal, R., Kumar, R., Hemalatha, R., Verma, V., Kumar, A., Chakraborty, C., Singh, B., Marotta, F., Jain, S. and Yadav, H. (2012). Cholesterol-lowering probiotics as potential biotherapeutics for metabolic diseases. Experimental Diabetes Research, 2012, 902917. https:// doi.org/10.1155/2012/902917.

Lin, T.Y., Wang, Y.J., Lai, P.Y., Lee, F.J. and Cheng, J.S. (1999). Cholesterol content of fried-shredded pork extracted by supercritical carbon dioxide. Food Chemistry, 67(1), 89-92. https://doi.org/10.1016/ S0308-8146(99)00098-9.

Liu, S., Yang, F., Zhang, C., Ji, H., Hong, P. and Deng, C. (2009). Optimization of process parameters for supercritical carbon dioxide extraction of Passiflora seed oil by response surface methodology. Journal of Supercritical Fluids, 48(1), 9-14. https:// doi.org/10.1016/j.supflu.2008.09.013.

Markom, M. and Singh, H. (2002). Extraction of crude palm oil using supercritical $\mathrm{CO}_{2}$. Jurnal Kejuruteraan, 14, 53-62.

Marzocchi, S., Pasini, F., Baldinelli, C. and Caboni, M.F. (2018). Value-addition of beef meat by-products: lipid characterization by chromatographic techniques. Journal of Oleo Science, 67(2), 143-150. https://doi.org/10.5650/jos.ess 17139.

McKenzie, D.J. (2002). Effects of dietary fatty acids on the respiratory and cardiovascular physiology of fish. Comparative Biochemistry and Physiology Part A: Molecular and Integrative Physiology, 128(3), 605619. https://doi.org/10.1016/s1095-6433(00)00338$\mathrm{x}$.

Micha, R., Wallace, S.K. and Mozaffarian, D. (2010). Red and processed meat consumption and risk of incident coronary heart disease, stroke, and diabetes mellitus. Circulation, 121(21), 2271-2283. https:// doi.org/10.1161/circulationaha.109.924977.

Mohamed, R.S., Neves, G.B. and Kieckbusch, T.G. (1998). Reduction in cholesterol and fractionation of butter oil using supercritical $\mathrm{CO}_{2}$ with adsorption on alumina. International Journal of Food Science and Technology, 33(5), 445-454. https://doi.org/10.1046/ j.1365-2621.1998.00195.x.

National Coordinating Committee on Food and Nutrition, Ministry of Health Malaysia. (2010). Malaysia Dietary Guidelines. Putrajaya, Malaysia: Technical Working Group on Nutritional Guidelines (for National Coordinating Committee on Food and Nutrition).

Ogunsola, O.O. and Omojola, A.B. (2008). Nutritional evaluation of a dehydrated shredded meat product, (Danbunama). Pakistan Journal of Nutrition, 7(4), 554-556. https://doi.org/10.3923/pjn.2008.554.556.

Patel, S., Kothari, D. and Goyal, A. (2011). Enhancement of dextransucrase activity of Pediococcus pentosaceus mutant SPAm1 by response surface methodology. Indian Journal of Biotechnology, 10, 346-351.

Perk, J., De Backer, G., Gohlke, H., Graham, I., Reiner, Ž., Verschuren, M., Christian, Pascale, B., Gudrun, B., Renata, C., Christi, D., Shah, E., Miles, F., Giuseppe, G., Richard, H., Arno, H., Sehnaz, K., Alessandro, M., Eva, P., Lars, R., Marti, S., Mikko, S., Wilma, J.M., Scholte, O.R., Christiaan, V., David, W., Jose, L.Z., Faiez, Z. and Wolpert, C. (2012). European Guidelines on cardiovascular disease prevention in clinical practice (version 
2012). European Heart Journal, 33(13), 1635-1701. https://doi.org/10.1093/eurheartj/ehs092.

Petrović, M., Kezić, N.A. and Bolanča, V. (2010). Optimization of the GC method for routine analysis of the fatty acid profile in several food samples. Food Chemistry, 122(1), 285-291. https:// doi.org/10.1016/j.foodchem.2010.02.018.

Pourmortazavi, S.M., Rahimi-nasrabadi, M. and Hajimirsadeghi, S.S. (2019). Supercritical fluid extraction in plant analysis. In Meyers, R.A. (Ed.) Encyclopaedia of Analytical Chemistry Theory and Instrumentation. United Kingdom: Wiley Online Library. $\quad$ https:// doi.org/10.1002/9780470027318.a9903.pub2.

Pourmortazavi, S.M., Saghafi, Z., Ehsani, A. and Yousef, M. (2018). Application of supercritical fluids in cholesterol extraction from foodstuffs: a review. Journal of Food Science and Technology, 55 (8), 2813-2823. https://doi.org/10.1007/s13197-0183205-z.

Rahman, M.S., Gul, K., Yang, H.S., Chun, J., Kerr, W.L. and Choi, S.G. (2019). Thermal and functional characteristics of defatted bovine heart using supercritical $\mathrm{CO} 2$ and organic solvent. Journal of the Science of Food and Agriculture, 99(2), 816823. https://doi.org/10.1002/jsfa.9250.

Salimon, J., Omar, T.A. and Salih, N. (2014). Comparison of two derivatization methods for the analysis of fatty acids and trans-fatty acids in bakery products using gas chromatography. The Scientific World Journal, 2014, 906407. https:// doi.org/10.1155/2014/906407.

Sánchez-Camargo, A.D.P., Parada-Alfonso, F., Ibáñez, E. and Cifuentes, A. (2017). On-line coupling of supercritical fluid extraction and chromatographic techniques. Journal of Separation Science, 40(1), 213-227. https://doi.org/10.1002/jssc.201601040.

Shao, Q., Huang, Y., Zhou, A., Guo, H., Zhang, A. and Wang, Y. (2014). Application of response surface methodology to optimise supercritical carbon dioxide extraction of volatile compounds from Crocus sativus. Journal of the Science of Food and Agriculture, 94(7), 1430-1436. https:// doi.org/10.1002/jsfa.6435.

Soliman, G.A. (2018). Dietary cholesterol and the lack of evidence in cardiovascular disease. Nutrients, 10 (6), $780 . \quad \mathrm{https}: / /$ doi.org/10.1080/09674845.2004.11732656.

Sukisman, A., Purnomo, H., Rosyidi, D. and Radiati, L.E. (2014). Quality properties, antioxidant capacity and total phenolic content of traditional deep-fried shredded meat (abon) of palu, central Sulawesi. American Journal of Food Technology, 9(2), 80-88. https://doi.org/10.3923/ajft.2014.80.88.

Taher, H., Al-Zuhair, S., AlMarzouqui, A. and Hashim, I. (2011). Extracted fat from lamb meat by supercritical CO2as feedstock for biodiesel production. Biochemical Engineering Journal, 55 (1), 23-31. https://doi.org/10.1016/ j.bej.2011.03.003.

Torres-Moreno, M., Torrescasana, E., Salas-Salvadó, J. and Blanch, C. (2015). Nutritional composition and fatty acids profile in cocoa beans and chocolates with the different geographical origin and processing conditions. Food Chemistry, 166, 125132.

https://doi.org/10.1016/ j.foodchem.2014.05.141.

Troy, D.J., Tiwari, B.K. and Joo, S.T (2016). Health Implications of Beef Intramuscular Fat Consumption. Korean Journal for Food Science of Animal Resources, 36(5), $577 . \quad \mathrm{https} / /$ doi.org/10.5851/kosfa.2016.36.5.577.

Vatansever, S. and Hall, C. (2020). Flavor modification of yellow pea flour using supercritical carbon dioxide + ethanol extraction and response surface methodology. Journal of Supercritical Fluids, 156, 104659. j.supflu.2019.104659.

Vedaraman, N., Brunner, G., Srinivasa Kannan, C., Muralidharan, C., Rao, P.G. and Raghavan, K.V. (2004). Extraction of cholesterol from cattle brain using supercritical carbon dioxide. Journal of Supercritical Fluids, 32(1-3), 231-242. https:// doi.org/10.1016/j.supflu.2003.11.010.

Vedaraman, N., Srinivasakannan, C., Brunner, G., Ramabrahmam, B.V. and Rao, P.G. (2005). Experimental and modeling studies on extraction of cholesterol from cow brain using supercritical carbon dioxide. Journal of Supercritical Fluids, 34 (1), 27-34. https://doi.org/10.1016/ j.supflu.2004.10.004.

Wang, H., Liu, Y., Wei, S. and Yan, Z. (2012). Application of response surface methodology to optimise supercritical carbon dioxide extraction of essential oil from Cyperus rotundus Linn. Food Chemistry, 132(1), 582-587. https:// doi.org/10.1016/j.foodchem.2011.10.075.

Wang, L., Weller, C.L., Schlegel, V.L., Carr, T.P. and Cuppett, S.L. (2008). Supercritical CO2 extraction of lipids from grain sorghum dried distillers grains with solubles. Bioresource Technology, 99(5), 13731382 . https://doi.org/10.1016/ j.biortech.2007.01.055.

Wehling, R.L., Froning, G.W., Cuppett, S.L. and Niemann, L. (1992). Extraction of cholesterol and other lipids from dehydrated beef using supercritical 
carbon dioxide. Journal of Agricultural and Food Chemistry, 40(7), 1204-1207. https:// doi.org/10.1021/jf00019a025.

World Health Organization. (2018). International statistical classification of diseases and related health problems (ICD-10). Geneva: World Health Organization.

Xu, X., Gao, Y., Liu, G., Wang, Q. and Zhao, J. (2008). Optimization of supercritical carbon dioxide extraction of sea buckthorn (Hippophae thamnoides L.) oil using response surface methodology. LWTFood Science and Technology, 41(7), 1223-1231. https://doi.org/10.1016/j.lwt.2007.08.002.

Zaibunnisa, A.H., Norashikin, S., Mamot, S. and Osman, H. (2009). An experimental design approach for the extraction of volatile compounds from turmeric leaves (Curcuma domestica) using pressurised liquid extraction (PLE). LWT - Food Science and Technology, 42(1), 233-238. https://doi.org/10.1016/ j.lwt.2008.03.015.

Zaidul, I.S., Selamat, J., Habib, A.S.M., Ferdosh, S., Akanda, M.J.H. and Jaffri, J.M. (2012). Optimization of supercritical co 2 extraction of fish oil from viscera of African Catfish (Clarias gariepinus). International Journal of Molecular Sciences, 13(9), 11312-11322. https:// doi.org/10.3390/ijms130911312.

Zermane, A., Larkeche, O., Meniai, A., Crampon, C. and Badens, E. (2016). Optimization of Algerian rosemary essential oil extraction yield by supercritical $\mathrm{CO} 2$ using response surface methodology. Comptes Rendus Chimie, 19(4), 538543. https://doi.org/10.1016/j.crci.2015.08.011. 